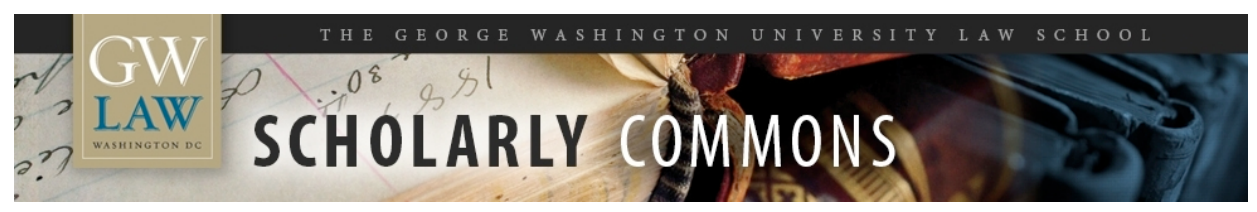

\title{
A Realistic Version of Campaign Finance Reform and Two Essential Steps Toward a Return to Effective Governance
}

Richard J. Pierce Jr

George Washington University Law School, rpierce@law.gwu.edu

Follow this and additional works at: https://scholarship.law.gwu.edu/faculty_publications

Part of the Law Commons

\section{Recommended Citation}

Pierce, Richard J., A Realistic Version of Campaign Finance Reform and Two Essential Steps Toward a Return to Effective Governance (2019). Pierce, Richard J. A Realistic Version of Campaign Finance Reform and Two Essential Steps Toward a Return to Effective Governance. Geo. Mason L. Rev. Forthcoming 2020; GWU Law School Public Law Research Paper No. 2019-41; GWU Legal Studies Research Paper No. 2019-41. Available at SSRN: https://ssrn.com/abstract=3429207

This Article is brought to you for free and open access by the Faculty Scholarship at Scholarly Commons. It has been accepted for inclusion in GW Law Faculty Publications \& Other Works by an authorized administrator of Scholarly Commons. For more information, please contact spagel@law.gwu.edu. 


\section{A Realistic Version of Campaign Finance Reform and Two Essential Steps Toward a Return to Effective Governance}

\section{Richard J. Pierce, Jr. ${ }^{1}$}

My main contribution to this symposium on "The Administration of Democracy" consists of a simple proposal to reform regulation of the process of financing a campaign for federal office. I urge Congress to eliminate most restrictions on contributions to campaigns and to impose on each campaign, political party and Political Action Committee (PAC) a duty to report every significant contribution publicly and promptly.

Given the breadth of the topic of the symposium, however, I cannot resist the opportunity to urge two other changes in our methods of governance that I believe to be essential to any effort to return to the democratic system of government that we once enjoyed. Those changes are elimination of primaries as the means through which political parties nominate candidates for office and elimination of what has come to be known as "the Hastert rule" - the rule that prohibits consideration of a Bill by the full House of Representatives unless it is supported by a majority of the members of the caucus of the party that has a majority in the House.

In section one I explain why it is impossible to implement a system of campaign finance reform that has any chance of furthering two of the potential goals of such a reform - taking money out of politics or creating conditions in which campaigns are fair to both candidates. In section two, I review and critique the main judicial decisions that have been issued in this area of law. I applaud the Supreme Court's treatment of the subject but express concern about one component of the D.C. Circuit's approach. In section three, I describe my proposed changes in law. We should remove virtually all restrictions on

\footnotetext{
${ }^{1}$ Lyle. T. Alverson Professor of Law at George Washington University.
} 
donations to the campaigns of candidates at the same time that we create a legal regime that insures that the public knows the source of all contributions within days after they have been received. Such a reformed system would decrease significantly the amount of irresponsible negative advertising in political campaigns and would allow each voter to decide whether to vote for a candidate who is supported by individuals the voter considers undesirable or untrustworthy.

In section four, I explain why we must eliminate our reliance on primaries as a means of choosing candidates for office and abolish the Hastert rule if we want to return to the system of democratic governance that we once enjoyed. The combination of primaries and the Hastert rule creates a political environment that is controlled by a small minority of the electorate with views that are on the extreme right or extreme left of the political spectrum. That combination renders it impossible for members of Congress to make the compromises that are essential to the ability of Congress to engage in bi-partisan legislative action. It also threatens to create an environment in which no president can staff the executive branch or fill vacancies in the judicial branch.

\section{Some Potential Goals of Campaign Finance Reform are Unrealistic}

If you accept the Supreme Court's interpretations of the First Amendment, ${ }^{2}$ as I do, it is impossible to create a system of campaign finance reform that will take money out of politics or that will create conditions in which elections are fair to each candidate. That explains why I propose a system that will further the more modest goals of reducing the amount of irresponsible negative advertising in campaigns and making the campaign finance system transparent so that voters can decide whether they want to support a candidate who takes money from individuals they dislike or distrust. Pursuit of those goals poses major challenges but I think they are plausible goals.

\footnotetext{
${ }^{2}$ E.g., Buckley v. Valeo, 424 U.S. 1, 143 (!976).
} 
I will emphasize one feature of our campaign finance regulatory system to illustrate the basis for my beliefs-the choice of decision making structure for the Federal Election Commission (FEC). When Congress enacted the Federal Election Campaign Act of 1971, it chose an unusual structure for the newlycreated Federal Election Commission (FEC), the agency that is responsible for implementing the Act. The FEC was to consist of six voting members. Two members were to be nominated by the President subject to confirmation by both the Senate and the House, while two were to be appointed by the Speaker of the House and two were to be appointed by the President pro tempore of the Senate. ${ }^{3}$

The legislative history of the Act confirms the obvious. Congress chose this structure because legislators assumed that every appointee will vote in accordance with the preferences of the politician who appoints the member and that every politician who appoints a member has an interest in his election or re-election that exceeds the politician's interest in any other issue. ${ }^{4}$ Thus, the members of the House and Senate feared that giving the president the sole role in nominating members of the FEC would create an agency that was biased in favor of the president and candidates for the House and Senate that the President preferred.

In Buckley v. Valeo, the Court called those fears "rational" and expressed its sympathy for "this sentiment as a practical matter. ${ }^{5}$ Yet, the Court held the structure of the FEC in the statute unconstitutional as a violation of the Appointments Clause. ${ }^{6}$ The FEC members are Officers of the United States who can only be appointed through the process of nomination by the president subject to confirmation by the Senate. The Court stayed its opinion for thirty days to allow Congress to amend the Act to conform it to the requirements of the Appointments Clause. ${ }^{7}$

\footnotetext{
3 Id. at $126-27$.

${ }^{4}$ Id. at 134.

${ }^{5}$ Id. at 134.

${ }^{6}$ Id. at $140-42$.

${ }^{7}$ Id. at 144.
} 
Congress responded to the Court's decision by amending the Act to comply with the Appointments Clause.

As amended, the Act gave the president the power to nominate each of the six voting members of the FEC, subject to confirmation by the Senate. ${ }^{8}$ The amended statute coupled that constitutionally-required change with three other features that reflected the continuing belief of members of Congress that FEC members will act in accordance with the biases of the politician who appointed the member. First, Congress retained the unique even-number of Commissioners structure despite its obvious disadvantage of inviting impotence attributable to frequent tie votes. Second, Congress provided that no more than three of the six Commissioners can be members of the same political party. Third, Congress mandated that the FEC must include the Secretary of the Senate or his designee and the Clerk of the House of Representatives or his designee as non-voting members.

In FEC v. NRA Victory Fund,${ }^{9}$ the D.C. Circuit refused to decide whether the no-more-than-three-members of the same political party restriction on the president's appointment power is unconstitutional. It concluded that the question is not justiciable except in the unlikely event that the president nominates and the Senate confirms four Commissioners who are members of the same party. ${ }^{10}$ The court held unconstitutional the provision that required the Clerk of the House and the Secretary of the Senate to be non-voting members. ${ }^{11}$ The court concluded that, since the non-voting members would influence the FEC's decisions, they too were Officers of the United States who could only be appointed through the process of nomination by the president and confirmation by the Senate. The court rejected the government's argument that the non-voting members would not be able to influence the decisions of the FEC because the only plausible reason Congress required their inclusion on the FEC was the expectation that they would influence the decisions of the FEC.

\footnotetext{
82 U.S.C. $\S 437 c(a)(1)(1988)$.

${ }^{9} 6$ F. 3d 821 (D.C. Cir. 1993), cert. dismissed, 513 U.S. 88 (1994).

${ }^{10}$ Id. at $824-25$.

${ }^{11}$ Id. at $826-27$.
} 
As amended by Congress and qualified by the D.C. Circuit, the FEC typically consists of three Republicans and three Democrats, each of whom was nominated by the president and confirmed by the Senate. That structure creates a predictable systemic problem. The FEC has little practical power because it frequently divides equally on straight party lines. ${ }^{12}$

Congress was so confident that the FEC members would act on the basis of the motives of the politicians who appointed them that it included in the statute unusual provisions that reflect that belief. The statute authorizes courts to review FEC decisions not to act ${ }^{13}$ and it authorizes citizen suits to enforce the statute when the FEC fails to act within 120 days of the filing of a complaint at the FEC. ${ }^{14}$ The congressional decision to include those provisions in the Act reinforce my belief that the FEC's dearth of practical power was an anticipated and intended effect of the structure Congress chose.

Given the universally shared belief that the head or heads of the FEC will act in accordance with the preferences of the politicians who appoint them, it is easy to conclude that the FEC structure Congress chose is better than the alternatives. If the FEC was headed by a single individual nominated by the president and confirmed by the Senate, the agency would be controlled by one of the two political parties during periods in which the Senate is controlled by the president's party. During such a period, the FEC would make all decisions in ways that would benefit the president's party and disadvantage the opposing party. If Congress had chosen the structure that is common for other multi-member agencies-five members, no more than three of whom can be members of the same party, it would be easy to predict the same result except that the decisions would be three-to-two in favor of the president's party.

\footnotetext{
${ }^{12}$ See Citizens for Responsibility and Ethics in Washington v. FEC, 923 F. 3d 1141, 1143 (D.C. Cir. 2019) (Pillard, dissenting from decision to deny rehearing en banc.)

${ }^{13} 52$ U.S.C. $\S 30109(a)(8)(A)$.

${ }^{14} 52$ U.S.C. $\S 30109(a)(8)(C)$.
} 
During periods in which the Senate is not controlled by the president's party, the FEC would often be powerless if it was structured in either of those traditional ways. As a result of predictable impasses between the president and the Senate in the appointment process, it would often be headless if it was headed by a single person and it would often lack a quorum if it was headed by five Commissioners.

Many observers of the FEC express dismay that it so often divides evenly on party lines. I would be more concerned if I saw a change from that pattern of decisions to a pattern in which the FEC decides many cases unanimously. I can imagine only two circumstances in which the FEC would decide lots of cases unanimously. That could happen as a result of capture of the FEC by a political party. That would make the agency an arm of one party-a result far worse than impotence.

The other possible cause of such a change is a situation in which all of the politicians who have roles in appointing FEC members share a common interest. They have a common interest in only one important context. They are all incumbents so they have a common interest in making decisions that favor incumbents. The FEC commissioners of both parties are likely to agree to make any decision that benefits incumbents and handicaps challengers. I would not consider that change from the status quo to be socially-beneficial.

The politicians who enact statutes that regulate contributions to campaigns share an interest in crafting rules that favor incumbents. It is easy to disguise rules that favor incumbents as even-handed rules that seem to enhance fairness. The statutory limits on campaign contributions appear to be fair and evenhanded because they impose the same limits on contributions to the campaigns of all candidates. That appearance is misleading, however. "Even-handed" statutory limits on campaign contributions create a 
systemic bias in favor of incumbents. It is more difficult, and more expensive, for a challenger to run a successful campaign than for an incumbent to run a successful campaign. ${ }^{15}$

I am confident that the politicians who voted for the contribution limits did so with full knowledge that the limitations have the effect of increasing the advantages that they, as incumbents, enjoy in all elections. Thus, the most basic characteristic of any system of regulating campaign finance-even-handed limits on the contributions that can be made to each candidate-is inconsistent with pursuit of the goal of regulating campaign finance to create a level playing field for each candidate. Campaign finance limits would create a level playing field only if incumbents were subject to much lower limits on campaign contributions than challengers-a form of campaign finance reform that no incumbent would support.

Some people might label my pessimistic perspective on the prospects for socially beneficial regulation of campaign finance as cynical. I prefer to think of it as realistic. It is no more cynical than the beliefs of the politicians who participated in the process of deciding how to structure the leadership of the FEC. Every decision Congress made in that process reflects the belief of politicians that they and their appointees will act in their own best interests as politicians who value re-election more than anything else.

\section{Constitutional Limits on the Power of Congress to Regulate Campaign Finance}

In its controversial decision in Citizens United v. FEC, ${ }^{16}$ a five-Justice majority of the Supreme Court held that Congress cannot limit the contributions that corporations and labor unions can make to political campaigns. My views on the potential good or bad effects of campaign finance regulation do not depend on whether the majority or dissent got the better of that argument.

\footnotetext{
${ }^{15}$ There is a rich scholarly literature that documents the advantages that incumbents enjoy in elections. E.g., Stephen Ansolabehere \& James Snyder, The Incumbency Advantage in U.S. Elections: An Analysis of State and Federal Offices, 1942-2000, Election Law Journal Vol. 1, No. 3 (2002).

${ }^{16}$ Citizens United v. FEC, 558 U.S. 310 (2010).
} 
My views have been influenced by the holdings of the Supreme Court in Buckley and of the D.C. Circuit in SpeechNow.org v. FEC. ${ }^{17}$ In its per curiam opinion in Buckley, the Supreme Court provided a good summary of its substantive holdings:

In summary, we sustain the individual contribution limits, the disclosure and reporting provisions, and the public financing scheme. We conclude, however, that the limitations on campaign expenditures, on independent expenditures by individuals and groups, and on expenditures by a candidate from his personal funds are constitutionally infirm. ${ }^{18}$

In its opinion in SpeechNow, the D.C. Circuit relied on the reasoning in Buckley as the basis for its holding that Congress cannot limit contributions to, or spending by, independent-expenditure-only political action committees. ${ }^{19}$

I agree with the holdings in Buckley and SpeechNow, but they create two practical problems. First, they provide an advantage to super rich candidates for office who can self-fund a campaign. Second, they create a powerful incentive to rely primarily on political action committees (PACs) and super PACs as the source of most of the money to finance a campaign and most of the advertisements to support candidates.

Individual contributions to campaigns for candidates are subject to a relatively low ceiling-- $\$ 2800$ per person at present. ${ }^{20}$ Political parties that operate independently of candidates can contribute to campaigns of candidates. Both individual contributions to the party and contributions of the party to a candidate are subject to a ceiling that is only slightly higher than the ceiling on individual's contributions to the campaign of a candidate--\$5000. ${ }^{21}$ PACs can support a candidate for office but cannot be affiliated

\footnotetext{
17599 F. 3d 686 (D.C. Cir.) (en banc), cert. denied 562 U.S. 1003 (2010).

18424 U.S. at 143.

${ }^{19} 599$ F. 3d at 692-94.

2052 U.S.C. $\S 30116 a(1)(A)$.

${ }^{21} 52$ U.S.C. $\S 30116 a(1)(C)$.
} 
with the campaign of the candidate and must operate independently of the candidate. PACs can contribute up to $\$ 5000$ to a candidate.

"Super PAC" is a term that refers to an independent-expenditure-only committee. ${ }^{22}$ Like a PAC, a super PAC cannot be affiliated with a campaign for a candidate and must operate independently of such a campaign. Contributions to a super PAC are not, and cannot be, limited. Super PACs account for a large and rapidly growing proportion of the money that is now spent in federal elections. ${ }^{23}$ In super PACs spent $84 \%$ of their money in support of incumbents. Ten super PACs accounted for $75 \%$ of total spending by super PACs. Most super PACs are supported by one or a few extremely rich individuals, many of whom contribute over a millions dollars to a single super PAC. Thus, for instance, a single donor gave $\$ 78$ million to super PACs associated with Republican candidates in $2016 ;^{24}$ a single donor gave $\$ 20$ million to the super PAC associated with Donald Trump's campaign; ${ }^{25} 85 \%$ of the money raised by the super PAC associated with Hillary Clinton's campaign came from donors who contributed at least one million dollars; ${ }^{26}$ and the top $1 \%$ of donors to super PACs in $2015-16$ accounted for $89 \%$ of all individual contributions to super PACs. ${ }^{27}$

In section I, I explained why campaign finance reform cannot create an election process that is fair to all candidates-any politically viable system will increase the advantages that incumbents have over challengers. Proponents of campaign finance reform often express a desire to further another goal-to take money out of politics. That is impossible if you accept, as I do, the holdings of Buckley and SpeechNow. Any attempt to limit the role of money in political campaigns through means such as limits on

${ }^{22}$ Congressional Research Service, The State of Campaign Finance Policy: Recent Developments and Issues for Congress 6-7 (Dec. 13, 2018).

${ }^{23}$ Miriam Galston, Buckley 2.0: How Would the Buckley Court Decide Buckley Today? forthcoming in Penn. J. Con. L. _ (2019).

${ }^{24}$ Galston, note _ supra., at _.

25 Id. at

${ }^{26}$ Id. at

27 Id. at 
contributions to campaigns and political parties will have only the effect of redirecting contributions from candidate campaigns to Super PACs.

Two other court opinions are important to my proposed method of reforming campaign finance reform. In FEC v. Akins, ${ }^{28}$ the Supreme Court held that Congress created a right to obtain information about political campaigns when it enacted the Federal Election Campaign Act and that any citizen has standing to challenge any action that the FEC takes that arguably interferes with that right. However, in Citizens for Responsibility and Ethics in Washington v. FEC, ${ }^{29}$ the D.C. Circuit undermined the effect of the holding in Akins by holding that many important FEC decisions cannot be reviewed by a court. In the next section of this essay I will explain why the holding in Akins is critical to my reform proposal and why the holding in Citizens for Responsibility and Ethics in Washington would render my proposal ineffective.

\section{Congress Should Deregulate Contributions to the Campaigns of Candidates and Require Prompt Public Disclosure of All Contributions to Any Political Committee}

My proposed reform of campaign finance is simple. Congress should repeal all limits on contributions to candidate campaigns and require all campaigns, political parties, PACs and super PACs to report all significant contributions promptly. Eliminating ceilings on contributions to candidate campaigns would encourage candidates to refocus their fund-raising efforts from super PACS to candidate campaigns. Over time, contributors would respond by shifting a high proportion of their contributions from PACs and super PACs to candidate campaigns. That would significantly improve the campaign finance system.

The constitution forbids Congress to limit contributions to super PACs. The absence of limits on contributions to super PACs, combined with the limits on contributions to the campaigns of candidates, creates a campaign finance system in which a large and growing proportion of the money contributed

\footnotetext{
28524 U.S. 11 (1998).

${ }^{29} 892$ F. 3d 434 (D.C. Cir. 2018), rehearing en banc denied, 923 F.3d 1141 (2019).
} 
goes to super PACs and a high proportion of political advertising is sponsored by super PACs. That is undesirable for several reasons.

First, advertisements sponsored by super PACs are less accurate and more negative than advertisements sponsored by candidates. Candidates must take responsibility for the advertisements they sponsor. They face a significant risk that an advertisement will backfire and hurt them if the public perceives it either as inaccurate or as unduly negative. ${ }^{30}$ Super PACs do not have to be concerned about either effect. A Super Pac can engage in inaccurate negative advertising without any concern that the candidate it supports will suffer any adverse effects.

The different incentives of super PACs and candidates have massive effects on the types of advertisements each sponsors. Almost all of the positive advertisements-85 per cent on average-are candidatesponsored ads. ${ }^{31}$ By contrast advertisements by super PACs are overwhelmingly negative-93 per cent were negative in $2010 .{ }^{32}$

Irresponsible and inaccurate negative advertisements have a systemic corrosive effect on public confidence in our political leaders. Many voters believe the claims that are made about opposing candidates in negative advertisements. ${ }^{33}$ Since super PACs that support each candidate sponsor many inaccurate negative ads, the winner of any election enters office with an undeserved bad reputation for honesty and integrity created by the negative advertisements sponsored by the super PACs that supported the opposing candidate. Eliminating the limits on contributions to candidate campaigns will reduce the amount of negative advertising and will increase the positive advertising by a corresponding amount. That will transform the political environment. Each successful candidate will enter office with a

\footnotetext{
${ }^{30}$ P.Motta \& Erika Franklin Fowler, Content and Effect of Political Advertising in U.S. Campaigns, Oxford Research Encyclopedia of Politics (Dec. 2016).

31 Id. at p.9.

32 Id. at p.9.

${ }^{33}$ Id. at p.15-16.
} 
much better reputation for honesty and integrity. That, in turn, will increase public confidence in government.

Second, it is virtually impossible for the FEC to enforce the prohibition on coordination between a campaign for a candidate and a super PAC that supports a candidate. ${ }^{34}$ It is common place, for instance, for a super PAC and a campaign to have officers, consultants, pollsters, and advertising firms in common. ${ }^{35}$ It is impossible to insure that the firms and individuals who work for the campaign do not communicate and coordinate with themselves in their capacities as employees and agents for the super PAC. As a result, candidates can use super PACs to take many actions that they dare not take directly. ${ }^{36}$

Third, it is easier to enforce reporting and disclosure requirements against campaigns for candidates than against super PACs. That relates logically to the other half of my proposed reform. Congress should amend the election laws in ways that require all organizations that play a role in politics to report all significant contributions promptly.

A comprehensive reporting and disclosure requirement would enable voters to learn who is supporting each candidate's campaign for office. A candidate could obtain advantages in the election by boasting about the sources of funding she is foregoing and by criticizing her opponent for taking money from questionable sources. That provides the public with the opportunity to decide whether it wants to elect a candidate who receives funding from sources the public dislikes or distrusts.

The Federal Election Campaign Act requires all candidates, political parties, PACs and super PACS to report the contributions they receive within ten days of receipt. ${ }^{37}$ However, the rules governing disclosure

\footnotetext{
${ }^{34}$ Galston, supra. note __, at __.

35 Id. at

${ }^{36}$ Id. at - .

3752 U.S.C. $§ 30104$.
} 
provide opportunities for evasion that are used routinely to enable candidates to hide sources of funding that the public dislikes or distrusts.

Miriam Galston has documented the methods that are regularly used to avoid disclosure of the identities of contributors whose support would elicit negative reactions from voters. ${ }^{38}$ They include disclosing incomplete or misleading names of donors and purchasing advertisements on credit, thereby delaying the duty to report the contributions used to repay the loans until after the election. Many of the evasions are facilitated by the laws governing organizations that are exempt from taxes. ${ }^{39}$

Social welfare organizations are exempt from taxes under IRC $\S 501$ (c)(4) as long as they do not devote too much of their revenue to political causes. As interpreted by IRS, $\S 501(c)(4)$ permits a social welfare organization to contribute up to 49 per cent of its expenditures to political activities, including contributions to super PACs. ${ }^{40}$ Exempt organizations are not required to report the identity of their contributors. As a result, individuals can evade the reporting system by donating to an exempt organization that, in turn, donates to a super PAC that supports a candidate.

Individuals who want to evade the reporting system also can take advantage of the tax exempt organization loophole in another way. They can create an exempt organization just before an election and use it as a conduit for making unlimited contributions to super PACs. ${ }^{41}$ By the time that IRS discovers that the organization has violated the limits on its political activities, the election is over.

Hundreds of millions of dollars in donations and hundreds of major donors escape the duty to report through use of these mechanisms in each election cycle. My proposal depends critically on the willingness

\footnotetext{
${ }^{38}$ Galston, supra. note __, at __.

${ }^{39}$ Miriam Galston, Vision Service Plan v. U.S.: Implications for Campaign Activities of 501(c)(4)s, 53 Exempt Org. T. Rev. 165 (2006). For updates see Galston, supra. note Groups and Campaign Spending (Oct. 18, 2018).

${ }^{40}$ Galston, supra. note __, at

${ }^{41}$ Galston, supra. note __, at , at _. See also Congressional Research Service: 501(c)
} 
of Congress to eliminate the many methods through which donors and candidates now evade the duty to report donations promptly. Professor Galston has described in detail the combination of actions that Congress must take to accomplish that result. ${ }^{42}$

The predictable impotence of the FEC is another obstacle to the efficacy of my proposal. The FEC is highly likely to refuse to enforce the reporting and disclosure requirements by declining to act in response to complaints of violations, often by 3 to 3 votes. The FEC's reluctance to enforce the reporting and disclosure requirements can be overcome by taking two steps. First, Congress must use extremely clear language in describing the duties to report and to disclose in order to empower courts to force the FEC to do its duty. Congress cannot trust the FEC to adopt interpretations of ambiguous statutory language that further the goal of insuring that all contributions are reported and disclosed promptly. ${ }^{43}$

Second, courts must open their doors to challenges to the FEC when it refuses to comply with the statute. The Supreme Court took an important step in the right direction in its decision in FEC v. Akins. ${ }^{44}$ The Court held that any citizen has standing to obtain review of any FEC decision that has the effect of violating the statutory right of the citizen to know who is contributing to political campaigns and organizations.

The D.C. Circuit took a step in the wrong direction in Citizens for Responsibility and Ethics in Washington v. FEC. ${ }^{45}$ The court held that courts cannot review 3-to-3 FEC decisions that refuse to initiate an enforcement proceeding in response to a complaint that some individual or entity violated the election laws. If courts refuse to review such decisions there is no realistic possibility that we can have any effective regulation of campaign finance, including my proposal to rely completely on transparency. Given the

\footnotetext{
${ }^{42}$ Id. at __, Galston, supra. note __, at

${ }^{43}$ While there are many points of disagreement about the extent of deference that a reviewing court should accord an agency's interpretation of the text of any legal document, there is unanimity that the starting point always is whether the statute or rule that is being interpreted is clear or ambiguous. If a statute or rule is clear, an agency interpretation is entitled to no deference. Kisor v. Wilkie, 139 S.Ct. U.S. 837, 843 (1984).

44524 U.S. 11.

45892 F. $3 d 434$ (D.C. Cir. 2018), rehearing en banc denied, 923 F.3d 1141 (2019). (2019); Chevron v. NRDC, 467
} 
composition of the FEC and the biases of its members, it is easy to predict that the FEC will refuse to enforce the law by a 3-to-3 vote in many cases in which the violation of law is clear.

I am encouraged by the separate opinions of two D.C. Circuit judges in response to the circuit's decision not to grant rehearing en banc. One judge dissented in a lengthy opinion in which he explained in detail why courts should review all 3-to-3 FEC decisions in which the FEC declines to take an enforcement action. ${ }^{46}$ Another judge wrote a concurring opinion in which he acknowledged the need to address that issue in a future case but expressed the view that the facts and briefing of the present case made it a poor vehicle for addressing reviewability. ${ }^{47}$

I recognize that the full transparency part of my proposal cannot be implemented unless Congress amends the laws applicable to reporting and disclosure and the courts enforce those laws when the FEC refuses to do so with a 3-to-3 vote. I believe that it is realistic to expect Congress to amend the statutes to create the potential for full transparency because members of Congress will not know whether such a change will help them or hurt them in the future. They will be acting behind the Rawlsian veil of

ignorance. ${ }^{48}$ I believe it is realistic to expect the courts to enforce the amended statute because I continue to have faith in the ability of life-tenured judges and Justices to enforce statutes in a manner that does not reflect partisan bias.

\section{Other Proposals to Improve the Administration of Democracy}

There are two other changes in the U.S. methods of implementing Democracy that I see as essential to restoration of a system of government that can function effectively. We must replace our present populist system of nominating candidates for office with a peer-based system, and both political parties must

\footnotetext{
46923 F.3d 1141, 1143 (dissenting opinion of Judge Pillard).

47923 F. 3d 1141 (concurring opinion of Judge Griffith).

48 John Rawls' concept of the veil of ignorance and its critical role in decision making is described in Original Position, Stanford Encyclopedia of Philosophy (Apr. 3, 2019).
} 
abandon what is referred to as the Hastert rule-the rule that a majority of the members of the caucus of the party that controls the House must support a Bill before it can be the subject of a vote by the full House.

There is broad agreement among scholars that our system of government has developed a major imbalance in the form of a transfer of undue power from the legislative branch to the executive branch. ${ }^{49}$ The power of the executive has increased dramatically because of the growing impotence of the legislative branch. ${ }^{50}$ Congress is capable of legislating only during the brief periods in which one political party controls the House, the Senate and the Presidency. During all other periods of time legislative gridlock prevails and precludes Congress from enacting any meaningful legislation except on a short- term emergency basis. Congressional impotence creates a void that can only be filled by the executive branch.

Congressional impotence is primarily a function of extreme and growing political polarity. ${ }^{51}$ Historians and political scientists have devoted a lot of time and energy to efforts to understand the complicated roots of that phenomenon. They have helped us understand why we have become so polarized but they have not yet identified any promising steps we can take to limit the increase in the political polarity of the electorate. That leaves us only with the option of trying to identify changes in our political institutions that have the potential to reduce the adverse effects of political polarity.

Without major changes in the composition of our political institutions, the incentives of the members of Congress, and the voting rules of Congress, we will experience increasing adverse effects of the failure of our version of Democracy. As statutes become increasingly obsolete, the executive branch will have no

\footnotetext{
${ }^{49}$ E.g., Jerry Mashaw \& David Berke, Presidential Administration in a Regime of Separated Powers: An Analysis of Recent American Experience, 35 Yale J. on Reg. 549 (2018); Dan Farber \& Anne Joseph O'Connell, The Lost World of Administrative Law, 92 Tex. L. Rev. 137 (2014); Peter Strauss, Overseer or the Decider? The President in Administrative Law, 75 Geo. Wash. L. Rev. 696 (2007).

${ }^{50}$ How to Measure a Dysfunctional, Gridlocked Congress, FIXGOV (June 28, 2016); Fred Dews, 3 Charts that Capture the Rise in Congressional Gridlock, Brookings Now (May 30, 2014).

${ }^{51}$ Darrell M. West, Divided Politics, Divided Nation (2019); Richard Pildes, Romanticizing Democracy, Political Fragmentation, and the Decline of American Government, 124 Yale. L. J. 804 (2016).
} 
choice but to try to stretch the power Congress has delegated to it in ways that put increased stress on the third branch-the judiciary. It is hard to see how judges can play constructive roles when they are regularly forced to choose between allowing the executive branch to exceed the boundaries of its delegated power and creating a situation in which no institution of government is capable of responding to the constantly changing needs of the nation.

There is also broad agreement that the president has increased his personal political power to an undesirable degree. ${ }^{52}$ Traditionally many important executive branch decisions were made by agency heads who were nominated and confirmed as officers of the United States because of their expertise in the areas in which they made decisions. Over time that system of executive branch decision making has been replaced by a system in which many decisions are made by anonymous white house political operatives who have no subject matter expertise and are motivated solely by their desire to aid the president and his supporters..$^{53}$ If left unchecked, increasing political polarity will accelerate the trend to replace the power of agencies headed by officers of the United States with the personal power of the president and anonymous white house aides.

Officers of the United States, judges, and Justices can be appointed only through the process of nomination by the President subject to confirmation by the Senate.${ }^{54}$ Confirmation votes have become increasingly partisan. ${ }^{55}$ With rare exceptions the members of the President's party vote to confirm his nominees and the members of the opposition party vote against confirmation.

\footnotetext{
${ }^{52}$ E.g., Mashaw \& Berke, supra. note ___ Strauss, supra. note

${ }^{53}$ Charles Clark, Vacancy Rate for Top Agency Jobs Continues to Set Records, Government Executive (Aug. 1, 2018); Anne Joseph O’Connell, Staffing Federal Agencies: Lessons from 1981-2016, Brookings Center on Regulation \& Markets (Apr. 27, 2017); Anne Joseph O'Connell, Shortening Agency and Judicial Vacancies Through Filibuster Reform? An Examination of Confirmation Rates and Delays from 1981 to 2014, 64 Duke L. J. 1645 (2015). ${ }^{54}$ U.S. Constitution Art. II, Sec. 2.

55
} 
This increasing trend has the potential to produce disastrous results during the many periods in which the Senate is controlled by the opposition party. The president will not be able to choose people to head agencies. He will have no choice but to centralize power in the White House, with aides who have not been confirmed for any office exercising most of the power that agencies traditionally exercised.

Increased political polarity can have similar devastating effects on the judiciary. During the many periods in which the White House and the Senate are controlled by different parties, the president will not be able to fill vacancies in the judiciary. A few years ago, I heard a scholar present a paper in which she discussed the serious problems that would exist if the Supreme Court no longer has the quorum that is required to make decisions. I was not concerned about the dysfunctional and impotent judicial branch she predicted as the result of such a situation because I believed that we would never find ourselves in that situation. I no longer discount that risk.

The stakes are high. We must identify ways of encouraging legislators to engage in the kinds of compromises with each other and with the president that are essential to our ability to legislate and to staff the executive and judicial branches of government. We must find ways of changing the composition of the legislative branch that reduce the adverse effects of political polarity.

The starting point should be the process of nominating candidates for office. Our present method of choosing candidates yields candidates who are not representative of the views of a majority of the members of either political party, at the same time that it discourages legislators from entering into the bipartisan negotiations that are essential to the compromises that can lead to legislation. ${ }^{56}$

\footnotetext{
${ }^{56}$ Richard Pildes, Why the Center Does Not Hold: The Causes of Hyperpolarized Democracy in America, 99 Cal. L. Rev. 273, 284 (2011).
} 
Primaries are low turnout elections. ${ }^{57}$ The few voters who choose to participate are the most ideologically extreme members of the party. ${ }^{58}$ As a result Democratic primaries select the candidates who are furthest to the left and Republican primaries select the candidates who are furthest to the right. Primaries create a legislative body that is more polarized than the electorate. That greatly reduces the likelihood that the members of the House and Senate can reach agreement on a compromise.

The primary process also greatly discourages members from compromising or even attempting to compromise. The vast majority of members represent districts or states that are "safe" in the sense that the candidate chosen by the member's party is virtually certain to win the general election. ${ }^{59}$ The only threat to a Senator in a "safe" state or a Congressman in a "safe" district arises as a result of the primary process. If the member compromises or threatens to compromise by moving to the center, she is virtually certain to face a primary challenger who has an excellent chance of defeating the member by running to her left if she is a Democrat or to her right if she is a Republican. The risk of being "primaried" is the only realistic risk that a representative of a "safe" state or district confronts. She knows that risk increases if she moves toward the center to compromise, so her only safe course of action is to avoid all compromises and to take positions that are on the left end of the ideological spectrum if she is a Democrat and on the right end of the ideological spectrum if she is a Republican. ${ }^{60}$

The alternative to party primaries are the methods that both political parties used in the U.S. until the 1970s and that most of the world's other Democracies use to choose candidates for office. ${ }^{61}$ The leaders

\footnotetext{
57 Id. at 298-99.

58 Id. at 298-99.

${ }^{59}$ Inside elections.com (2016); Stacey Hunt \& David Schultz, Presidential Swing States: Why Only Ten Matter (2015).

${ }^{60}$ Richard Pierce, Finding a Path Back to Democratic Governance, Regulatory Review (Feb. 26, 2018).

${ }^{61}$ There are many good descriptions and analyses of the changes in the nomination process the U.S. made in the 1970s. E.g., Aram Goudsouzian, The Men and the Moment (2019);Stephen Gardbaum \& Richard Pildes, Populism and Institutional Design: Methods for Selecting Candidates for Chief Executive, 93 N.Y.U. L. Rev. 647 (2018); Elaine Kamarck, Returning Peer Review to the American Presidential Nominating Process, 93 N.Y.U. L. Rev. 709 (2018); Elaine Kamarck, Primary Politics (3d ed. 2018); Pildes, supra. note _ at 287-315.
} 
of the party choose the candidates based on a combination of a correspondence between the potential candidate's values and the values of the party and an evaluation of the probability that the potential candidate will win the general election. Rick Pildes refers to these traditional methods of choosing candidates as peer-based. ${ }^{62}$ Since the dominant views of the electorate that participates in the general election are invariably near the right end of ideological spectrum of the members of the Democratic party and near the left end of the spectrum of the members of the Republican party, the party leaders have a powerful incentive to nominate centrists. The candidates who win the general election then have an incentive to take centrist positions on issues and to compromise with the members of the opposing party so that they can claim success in the legislative process.

A House and Senate whose members are nominated through use of a peer-based method are far more likely to be able to make the bipartisan compromises that are essential to the process of enacting legislation. A Senate whose members are chosen through use of a peer-based system are also far more likely to be willing to engage in the compromises with the president that are essential to the process of choosing and confirming nominees to be Officers, Judges and Justices that are essential to the process of staffing the Executive and Judicial branches.

Elimination of the "Hastert rule" is almost as important to our ability to function as a Democracy as elimination of party primaries. The Hastert rule prohibits the Speaker of the House from bringing any Bill to the floor for a vote unless a majority of the members of the Speaker's caucus support the Bill. ${ }^{63}$ The Hastert rule has the effect of giving a minority of the members of the House the power to veto any Bill even if it would get a favorable vote from a majority of the members if it could make it to the floor for a vote. The majority of the members of the caucus (and minority of the members of the House) who have

\footnotetext{
${ }^{62}$ Gardbaum \& Pildes, supra. note ___; Pildes, supra. note ___.

${ }^{63}$ For discussion of the rule and its effects see Sarah Binder, Are the Days of the Hastert Rule Numbered? Some Caution in Reading the House, Brookings Op-Ed (Mar. 1, 2013).
} 
this veto power are always the most far right members of the Republican caucus or the most far left members of the Democratic caucus.

Elimination of the Hastert rule would be effective only if it is coupled with a new method of selecting the Speaker of the House. Bill Galston and the Problem Solvers Caucus of House Members that he advises have proposed a rule that would require a candidate for Speaker to obtain a two-thirds majority of the members of the House to be elected. ${ }^{64}$ That change in the composition of the electorate required to elect the Speaker would create an environment in which the Speaker is likely to be a centrist. The Speaker would then have a completely different set of incentives to determine the agenda of the House by allowing floor votes on Bills that have strong bipartisan support even if they are opposed by a majority of the members of the Speaker's party.

The combination of the primary process, the Hastert rule and the present method of electing the Speaker of the House produces a situation in which a minority of a minority can veto any Bill. The minority with the veto power lies on the far right fringe of the Republican party and the far left fringe of the Democratic party. If we eliminate both the primary process and the Hastert rule and change the method of choosing the Speaker, we will return to an institutional environment in which the members of both the House and the Senate are more representative of the views of a majority of the electorate and in which they are far more likely to be able to perform the critical tasks of enacting legislation and choosing the Officers who will make policy decisions in the Executive Branch and the Judges and Justices who will ensure that all of the political actors stay within the legal boundaries on their powers.

I realize that the combination of changes that I urge have little chance of being adopted today. The prospects for their adoption will improve dramatically, however, when the disastrous consequences of

\footnotetext{
${ }^{64}$ Carl Hulse, Can the House Speakership Be Saved, These Lawmakers Have an Idea, New York Times (June 16, 2018); Tom Davis, How to Fix Washington, Step One, The Hill (Mar. 1, 2018); William Galston, To Fix the House, Start with the Speaker, Wall Street Journal (Feb. 27, 2018).
} 
the status quo that I foresee become a reality so stark that the flaws in the characteristics of our present institutions cannot be ignored or denied. 
